Article

\title{
Aesthetic Alteration of Marble Surfaces Caused by Biofilm Formation: Effects of Chemical Cleaning
}

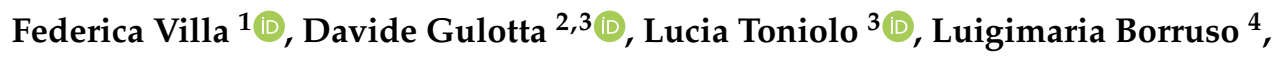 \\ Cristina Cattò ${ }^{1}$ (D) and Francesca Cappitelli ${ }^{1, *(D)}$ \\ 1 Department of Food Environmental and Nutritional Sciences, Università degli Studi di Milano, via Celoria 2, \\ 20133 Milano, Italy; federica.villa@unimi.it (F.V.); cristina.catto@unimi.it (C.C.) \\ 2 Getty Conservation Institute, Science Department, 1200 Getty Center Drive, Los Angeles, CA 90049, USA; \\ DGulotta@getty.edu \\ 3 Department of Chemistry, Materials and Chemical Engineering “Giulio Natta”, Politecnico di Milano, \\ 20131 Milano, Italy; lucia.toniolo@polimi.it \\ 4 Faculty of Science and Technology, Free University of Bozen, piazza Università 5, 39100 Bolzano, Italy; \\ luigimaria.borruso@unibz.it \\ * Correspondence: francesca.cappitelli@unimi.it; Tel.: +39-0250319121
}

Received: 23 December 2019; Accepted: 29 January 2020; Published: 1 February 2020

\begin{abstract}
Despite the massive presence of biofilms causing aesthetic alteration to the façade of the Monza Cathedral, our team in a previous work proved that the biocolonization was not a primary damaging factor if compared to chemical-physical deterioration due to the impact of air pollution. Nonetheless, the conservators tried to remove the sessile dwelling microorganisms to reduce discolouration. In this research, two nearby sculpted leaves made of Candoglia marble were selected to study the effects of a chemical treatment combining the biocides benzalkonium chloride, hydrogen peroxide and Algophase ${ }^{\circledR}$ and mechanical cleaning procedures. One leaf was cleaned with the biocides and mechanically, and the other was left untreated as control. The impact of the treatment was investigated after 1 month from the cleaning by digital microscopy, environmental scanning electron microscopy, confocal microscopy and molecular methods to determine the composition and the functional profiles of the bacterial communities. Despite the acceptable aesthetic results obtained, the overall cleaning treatment was only partially effective in removing the biofilm from the colonized surfaces and, therefore, not adequately suitable for the specific substrate. Furthermore, the cleaning process selected microorganisms potentially more resistant to biocides so that the efficacy of future re-treatment by antimicrobial agents could be negatively affected.
\end{abstract}

Keywords: biofilm; discoloration; Candoglia marble; biocidal treatment; benzalkonium chloride; hydrogen peroxide; metabolic pathways

\section{Introduction}

The investigated stone is Candoglia marble from the façade of the Monza Cathedral, a Northern Italian architectural masterpiece. The façade was built starting from the 14th century exploiting several sedimentary and metamorphic rocks, including different types of marble and a serpentinite. The cladding and the decorative elements made of Candoglia marble belong to a later phase of construction and restoration dating back to the early 20th century.

In previous work by our team [1], we proved that despite the massive presence of biofilms causing aesthetic alteration to the façade of Monza Cathedral, the biocolonization was not a primary damaging factor if compared to chemical-physical deterioration due to the aggressive polluted atmosphere. Nonetheless, the conservators of the Monza Cathedral have tried to remove the sessile dwelling microorganisms to reduce discoloration based on their previous experiences in similar cases. 
The common strategy for eliminating biofilms from stone heritage sites in outdoor conditions has been the application of biocides [2]. Biocides have successfully been applied to control the growth of all major microbial deteriogens, including lichens [3], algae [4], cyanobacteria [5], actinobacteria and other chemotrophic bacteria [6] and fungi [7]. Among biocides, quaternary alkylammonium compounds, including benzalkonium chloride, are frequently used in conservation [8]. According to Mulder et al. [9], these compounds are characterized by the combination of positive charge and hydrophobic alkyl chains with amphiphilic features that make them valid surfactants and good antimicrobial disinfectants. Their antimicrobial activity against bacteria causes the disruption of membrane integrity, resulting in a leakage of cellular content [9]. Hydrogen peroxide $\left(\mathrm{H}_{2} \mathrm{O}_{2}\right)$ has also been used to kill phototrophs [10,11]. For instance, Jurado et al. [12] used $\mathrm{H}_{2} \mathrm{O}_{2}$ in the Castañar de Ibor Cave because when in contact with organic matter the molecule decomposes into harmless products (water, oxygen and $\mathrm{CO}_{2}$ ) and can be easily applied by the operators without health risks and special precautions. Algophase (n-butil-1,2benzoisothiazolin-3-one), which has been mainly used against cyanobacteria, algae and lichens [13], displayed a more satisfactory action on some areas of the Erechtheion, Athens, Greece, in comparison with other biocides tested [6].

According to the general requirements for the treatment of stone heritage surfaces, biocides must neither harm the substrate from the chemical point of view nor induce significant changes of its appearance. In practice, however, a number of authors have emphasized the possible damage induced by biocidal treatments, which includes surface erosion and/or surface roughening, staining, changes in the capillary water absorption behavior and increased vulnerability to pollutants [2,14]. Additionally, Maxwell [15] claimed that cleaning could encourage rainwater penetration into the stone.

In outdoor conditions, as the cleaned condition is a temporary state, recolonization is inevitable [2]. This means that the employment of biocides should not be considered as a long-term solution [16,17]. The fungi identified on historical stuccos by Favero-Longo et al. [18] were firstly inhibited by applications of benzalkonium chloride and isothiazolinones, however, after only a few days they were able to re-grow. Thus, the researchers suggested monitoring microbiological susceptibility to biocides well after the treatment. Recolonization can be more aggressive than the first colonization. A biocidal treatment used on the monuments at the Angkor site in the 1990s led to a subsequent worsening recolonization that was characterized by intensive blackening of the treated stone surfaces caused by black-pigmented cyanobacteria [19].

Importantly, for all the issues above and as most if not all commercial biocides applied on stone are toxic or otherwise polluting substances [20], a careful preliminary study on the possible pros and cons of biocidal treatments on heritage stone is required. Generally, stone-conservation literature reports about the comparison of efficacy of biocides in order to suggest the most efficient product $[6,21]$. However, to avoid the development of resistance, it is advisable to employ treatments with two or more biocidal molecules [22,23]. Consequently, here a pilot area on the Monza Cathedral façade (Figure 1a) was selected with the aim of studying the effects of a treatment based on the combination of the three biocides benzalkonium chloride, hydrogen peroxide and Algophase ${ }^{\circledR}$ and mechanical cleaning. To date, viable cell count is often the method of choice to prove biocidal effects [8]. Moreover, conservation literature has shown the importance of evaluating biocidal treatments in situ without cultivating the microorganisms [21]. In this research, we investigated the impact of the biocidal treatment on stone in situ with digital, environmental scanning electron and confocal microscopy and molecular methods, avoiding cultivation. 


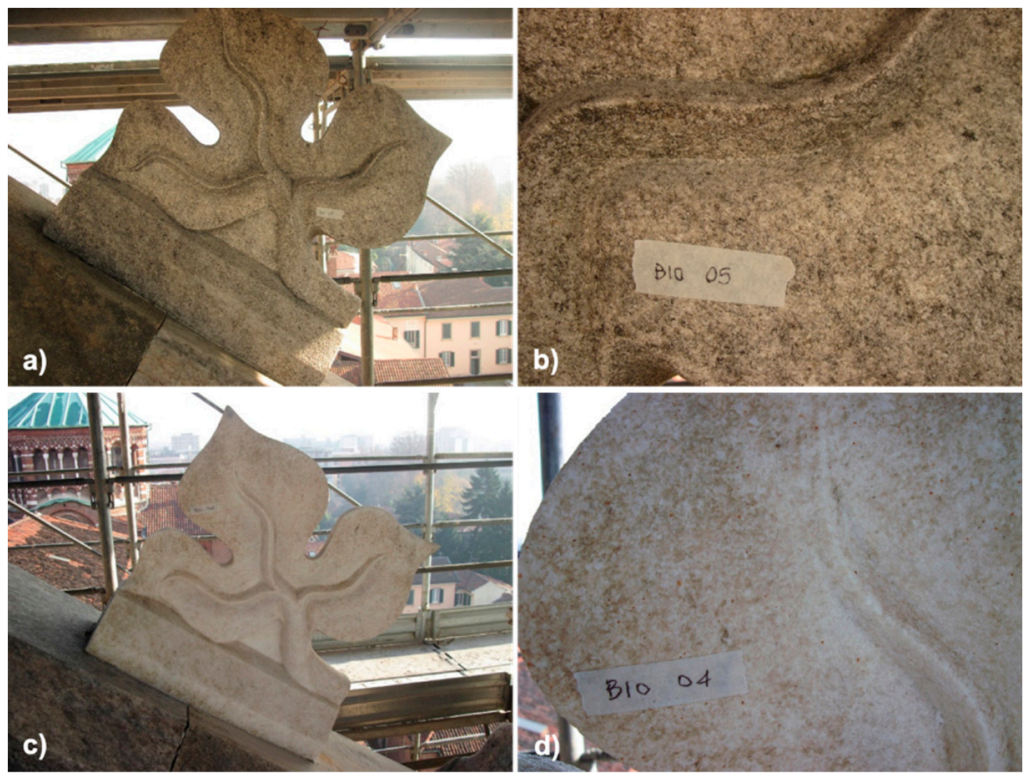

Figure 1. Photographic documentation of the Candoglia untreated (a) and treated (c) leaves, and details of the sampling areas untreated and treated areas $(\mathbf{b}-\mathbf{d})$ respectively.

\section{Materials and Methods}

\subsection{Sampling Sites and Chemical and Mechanical Cleaning Treatment}

Samples of Candoglia marble (stone fragments with an average surface of about $5 \times 5 \mathrm{~mm}$ and average thickness around $2 \mathrm{~mm}$ ) for the laboratory investigation were collected from two nearby decorative elements (sculpted leaves) of the top raking cornice of the façade one month after the cleaning treatment conducted in the framework of the pilot site activity for the definition of the conservation methodologies [24]. One leaf was treated with biocides and the other was left untreated as control.

The chemical and mechanical cleaning treatment applied to the marble leaf was as follows: (1) preliminary mechanical brushing of the surface, (2) application of $5 \%$ benzalkonium chloride by brush; (3) mild mechanical brushing 5 days after the application; (4) application of hydrogen peroxide via a cellulose fibers poultice (Arbocel) for 5 days; (5) wet brushing of the surface and (6) application of Algophase ${ }^{\circledR}$ (Phase, Italy, 3\% dilution in isopropyl alcohol; active ingredient: 2,3,5,6-tetrachloro-4-methylsulfonyl-pyridine) by brush. This cleaning treatment was designed and performed by the conservators according to their previous experiences in similar cases.

\subsection{Stone Characterization and Evaluation of the State of Conservation}

The on-site observation and documentation of the stone substrate was conducted using a Dino-Lite Premiere AM7013MT digital microscope (New Taipei City, Taiwan), equipped with a colour CMOS sensor and a white light-emitting diode (LED) illuminator.

Stone fragments were collected by scalpel and chisel and were prepared in polished cross-sections using a bi-component epoxy resin (Mecaprex MA2+, Presi, Eybens, France). The mineralogical characterization of the substrates was performed on powdered samples by a Philips PW1830 X-ray diffractometer (XRD) (Malvern, UK) using Cu K $\alpha$ radiation $(\lambda=154,058 \AA$ ), PW3020 generator and Bragg-Brentano geometry. The morphological features of fragments and polished cross-sections of the substrates before and after the treatment were investigated by environmental scanning electron microscopy (ESEM) and energy-dispersive X-ray (EDX) analyses, using a Zeiss EVO 50 EP ESEM (Jena, Germany), equipped with an Oxford INCA 200 - Pentafet LZ4 spectrometer (Jena, Germany). 


\subsection{Visualization of Biofilm Structure}

For the visualization of the biofilm structure, samples were collected using the non-invasive method of adhesive tape strips. Strips were gently applied onto the stone surface and were then placed on sterile glass microscope slides and kept in a box until arrival in the laboratory. The adhesive tape strips were immediately analyzed by confocal laser-scanning microscopy (CLSM) (Nikon A1R, Milan, Italy). The structure and the architecture of biofilms growing on different lithic surfaces were observed in both fluorescence and reflection modes as previously reported by Villa et al. [25]. The reflection mode (excitation at $488 \mathrm{~nm}$, and emission at 480 to $490 \mathrm{~nm}$ ) allowed the recording of reflective signals originating from inorganic solid material. Autofluorescence from photosynthetic pigments was viewed in the red channel using the $633 \mathrm{~nm}$ line of an $\mathrm{Ar} / \mathrm{HeNe}$ laser in the emission range of 650 to $750 \mathrm{~nm}$. The Syto9 stain (Thermo Fisher Scientific, Milan, Italy) was used to visualize live cells, according to the manufacturer's instructions. In brief, a small area of the adhesive tape was covered with $5 \mu \mathrm{M}$ Syto 9 in water and incubated for 15 minutes in the dark at room temperature. After incubation, the sample was rinsed three times with water to remove the residual staining. Signal from Syto9 was captured in the green channel using an Argon gas laser, with excitation at $488 \mathrm{~nm}$ and emission range of 500 to $550 \mathrm{~nm}$.

A total of 10 images were analyzed with the software Imaris (Bitplane Scientific Software, 9.2, Switzerland) for 3D reconstructions of biofilm samples. Living phototrophic and the chemotrophic microorganisms were distinguished by coupling the results from Syto9 staining with those obtained from pigment autofluorescence signals.

The emission spectra of photosynthetic pigments were obtained using a wavelength $\lambda$-scan function of the CLSM before any staining as reported by Roldán et al. [26]. Regions of interest (ROIs) representing single cells were used to obtain fluorescence spectra. Representative fluorescence spectra of phototrophic cells within biofilms are presented.

\subsection{DNA Extraction and Sequencing}

Samples for metagenomics analyses were collected by gentle scraping off biofilms from the stone surfaces with a sterile scalpel. Samples were powdered using sterile tubes and pestles and DNA was immediately extracted from $\sim 0.1 \mathrm{~g}$ of homogenized sample by using a modified phenol-chloroform protocol, as previously described by Polo et al. [27]. The quantity and the quality of extracted nucleic acids were measured by a NanoDrop ${ }^{\circledR}$ ND-1000 Spectrophotometer (Thermo Fisher Scientific Inc., Milan, Italy). The extracted DNA from 2 replicates of each condition (untreated and treated substrates) was combined.

High-throughput sequencing analysis of the V3-V4 region of the bacterial 16S rRNA gene (primers CS1_341F/CS2_806R) was performed by using a MiSeq platform (Illumina) with v3 chemistry providing $2 \times 300$ paired-end reads [28].

Raw data were pre-processed, quality filtered, trimmed, de-noised, paired, and modeled via QIIME2 [29] and DADA2. Chimeras were detected using DADA2 according to the "consensus" method [30]. Sequences were clustered into amplicon sequence variants (ASVs). ASVs were assigned using a Naïve-Bayes classifier trained on the SILVA database [31]. Samples were rarefied at the minimum library size of 5246 .

The functionality of the bacterial communities was investigated via the Phylogenetic Investigation of Communities by Reconstruction of Unobserved States 2 (PICRUSt2) v.2.1.3-b software using default parameters [32]. The functional pathways differentially enriched in the treated sample were obtained by calculating the ratio of the functional gene copy number for all the categories inferred by PICRUSt. Ratios higher than 2 were considered in this study.

Multi packages of $\mathrm{R}$ software were used to calculate the alpha diversity (Richness, Shannon, Simpson, and Evenness), to generate the rarefaction curves and the Venn diagram [33]. 


\section{Results}

\subsection{Evaluation of the State of Conservation of the Stone Substrate before and after the Cleaning Treatment}

Candoglia marble is a medium-grained highly compact (average porosity of the fresh stone around $1 \%$ ) calcitic marble quarried close to Lake Maggiore (Verbania, Italy). It has been traditionally employed as building and cladding material of major architectural landmarks in Northern Italy, including the Cathedral of Milan. The main mineralogical phase is calcite, with minor quartz and presence of pyrite. The complete mineralogical and compositional characterization of Candoglia marble samples from the façade of the Monza cathedral has been reported in a previous work [1].

The sculpted Candoglia marble elements located on top of the raking cornices of the façade are particularly subject to the combined effect of rain-wash and of prolonged exposure to a highly polluted urban atmosphere. As a result, the current state of conservation of these elements is characterized by intense surface erosion and by the presence of black and dark green biofilms. The on-site close observation of the surface by digital microscopy highlighted the irregular distribution of the biofilm, which was particularly concentrated along the grain boundaries and within the cleavage planes of the marble. The biofilm could mostly be observed as a dark cluster-like deposit (Figure 2a), whereas in some areas of the stone larger and isolated spot-like formations could also be identified.
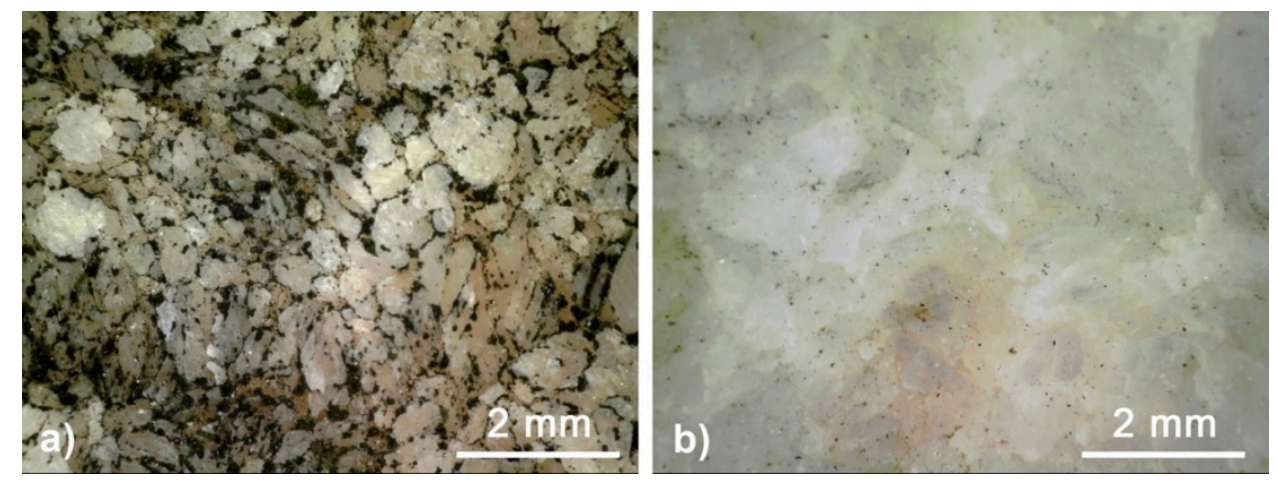

Figure 2. On-site digital microscopy documentation of the (a) untreated and (b) treated stone surface at the same magnification.

Upon cleaning, the characteristic medium-grained morphology of the marble substrate was revealed but the treatment seemed not to be able to completely remove the biofilm, as evidenced by the residual presence of diffused dark spots and yellowish areas on the surface. Such residual traces were particularly preserved where the stone corrosion was more intense, i.e. along the grain borders and cleavage planes (Figure $2 b$ ).

These findings were confirmed by the investigation at higher magnification via ESEM. In particular, the colonized surface appeared extensively but irregularly covered by the biofilm, which also embedded loose mineral grains and particulate matter, so that the typical features of the stone substrate could not easily be observed (Figure 3a,b). The biofilm was able to penetrate the highly corroded mineral matrix, filling the micro-cracks and detached cleavage planes (Figure 3a,b). After cleaning, the most superficial part of the biofilm was removed and, as a result, the extent of the intergranular corrosion affecting the stone matrix could be fully appreciated. The biofilm, which had penetrated within the micro-cracks and voids, was not entirely removed (Figure 3c,d). 

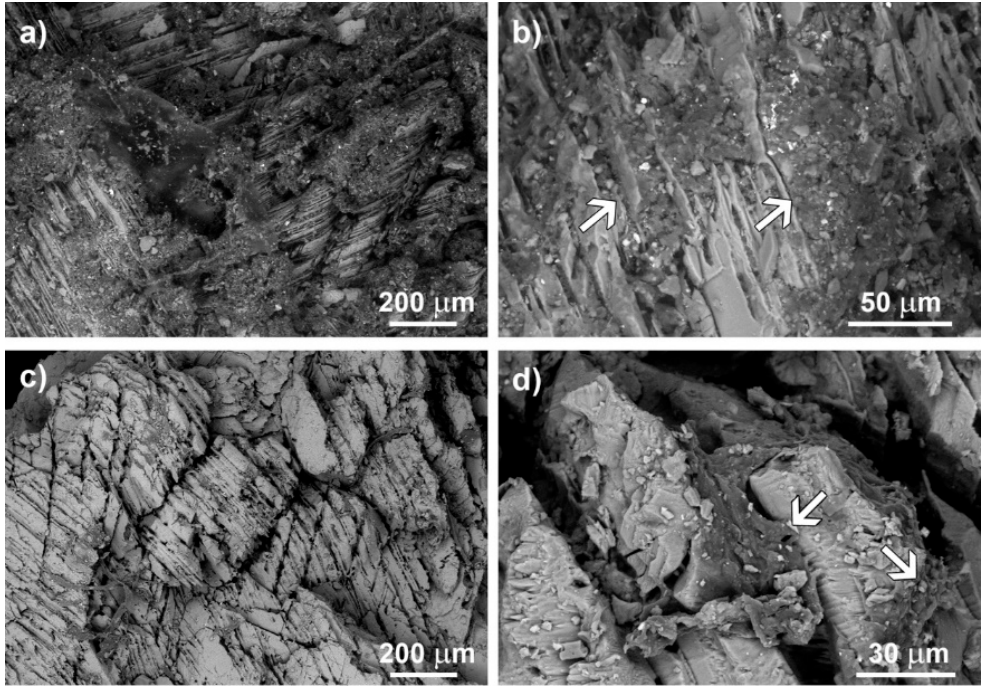

Figure 3. Environmental scanning electron microscopy (ESEM) micrographs of the untreated $(\mathbf{a}, \mathbf{b})$ and treated $(\mathbf{c}, \mathbf{d})$ stone substrate. The arrows indicate the extensive colonization covering the mineral substrate (b) and the residual presence of the biofilm (d) after the treatment.

\subsection{Biofilm Characterization}

Representative images of biofilm architectures for the untreated and treated surfaces are presented in Figures 4 and 5, respectively. The images correspond to the three dimensional blend reconstructions obtained from confocal images series with the dedicated IMARIS software (version 9.2).

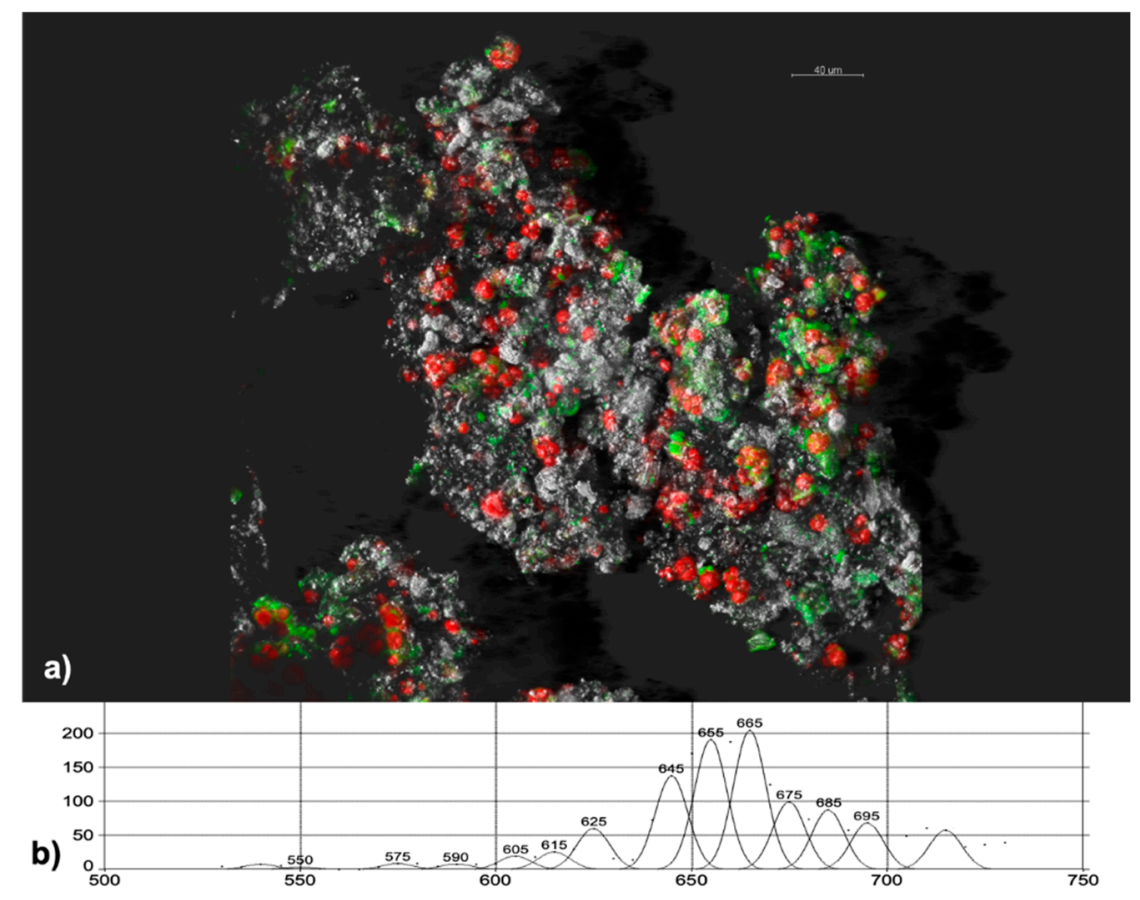

Figure 4. (a) Confocal laser scanning imaging of biofilm growing on untreated Candoglia marble. Colour key: phototrophs, red (autofluorescence); chemotrophs, green (Syto9); stone, grey (reflection). Scale bars are $40 \mu \mathrm{m}$. (b) Emission spectrum recorded from coccoid cyanobacterial cells. Spectral profile shows individual phycobiliproteins: phycoerythrin, $575 \mathrm{~nm}$; phycocyanin, $645 \mathrm{~nm}$; allophycocyanin, $665 \mathrm{~nm}$; chlorophyll a, $685 \mathrm{~nm}$. 

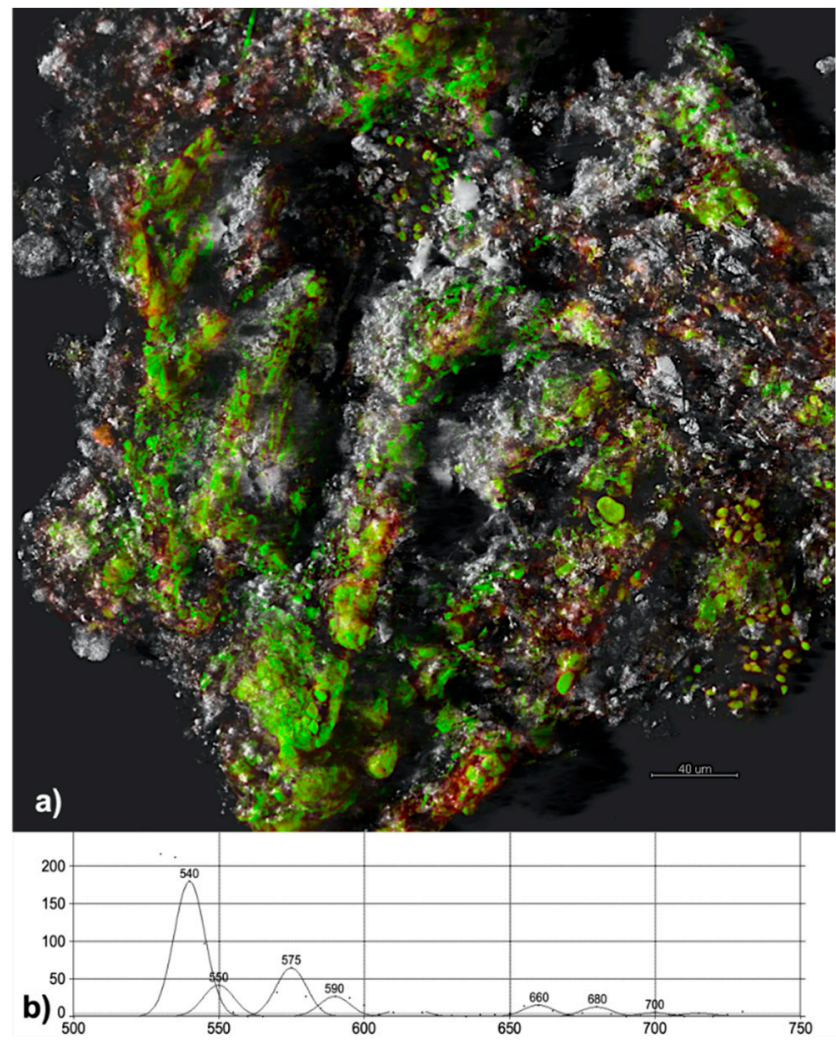

Figure 5. (a) Confocal laser scanning imaging of biofilm growing on treated Candoglia marble. Colour key: phototrophs, red (autofluorescence); chemotrophs, green (Syto9); stone, grey (reflection). Scale bars are $40 \mu \mathrm{m}$. (b) Emission spectrum recorded from coccoid cyanobacterial cells. The spectral profile shows characteristic emission peaks between 540 and $590 \mathrm{~nm}$ corresponding to thylakoid disorganization.

The epilithic biofilm on untreated Candoglia marble was characterized by a cyanobacterial-rich microbial community dominated by a coccoid morphotype assembled in clusters (Figure 4). The spaces around the aggregates of coccoid cyanobacteria were filled with multicellular clusters of chemotrophic bacteria.

The CLSM lambda-scan feature was used to characterize the fluorescence emitted by cyanobacterial photosynthetic pigments for assessing the physiological state of phototrophs at the single-cell level. The phototrophic microorganisms observed on the untreated substrate showed mainly a coccoid form and autofluorescence emission signals within the red range in response to 488-nm laser excitation. The coccoid photosynthetic cells exhibited characteristic emission peaks between 645 and $685 \mathrm{~nm}$, corresponding to phycobiliproteins and chlorophyll a (Figure $4 \mathrm{~b}$ ). These cells were classified as viable and healthy as reported by Roldán et al. [26].

The epilithic biofilm on treated Candoglia marble presented an extensive green signal, while the red signal was limited to few small areas. When excited at a wavelength of $488 \mathrm{~nm}$, cyanobacterial cells on the treated substrate showed an autofluorescence within the green range with characteristic emission peaks between 540 and $590 \mathrm{~nm}$ (Figure 5b). These cells corresponded to those showing extensive thylakoid disorganization, and were then considered non-viable [26].

Interestingly, the green signal corresponding to Syto9 stain appeared to be spread across the mineral surface (Figure 5a). This result indicated the presence of intracellular material on the marble, which may suggest that dead cells were not completely removed after the cleaning treatment. 


\subsection{Effects of the Cleaning Treatment on the Biofilm Composition}

High-throughput sequencing with an Illumina MiSeq platform was used to analyze the structure and composition of the bacterial community colonizing the untreated and treated Candoglia marble leaves.

After bioinformatics analysis, a total of 27,272 reads were assigned as Bacteria, where 22,026 and 5246 were attributed to the untreated and treated samples, respectively. The reads were clustered in 160 ASVs, distributed as follows: 139 ASVs from the untreated sample and 21 ASVs from the treated one. Only 11 ASVs were shared among the samples (Figure 6a). The rarefaction curve in Figure $6 \mathrm{~b}$ asymptotically approached a plateau, suggesting that the sequencing depth was sufficient for a thorough description of the bacterial communities.

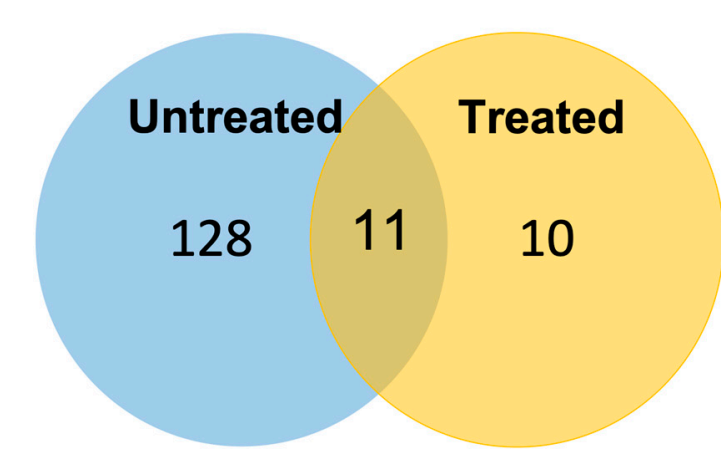

a)

Figure 6. Panel (a) represents the Venn diagram, which illustrates overlap of bacterial amplicon sequence variants (ASVs) between treated and untreated samples. Numbers inside circles indicate the number of unique ASVs in one of the subsets. The number in the overlapping region indicates the number of shared ASVs between samples. Panel (b) display the rarefaction curves of the bacterial communities based on 16S rRNA gene sequences.

Amplicon sequences of the untreated samples were classified into 12 different phyla: Proteobacteria, Cyanobacteria, Actinobacteria, Deinococcus-Thermus, Bacteroidetes, FBP, Acidobacteria, Chloroflexi, Gemmatimonadetes, Patescibacteria, Planctomycetes and Armatimonadetes (Figure 7a, Table S1).

Proteobacteria were the primary components of the bacterial communities in the untreated samples, accounting for $27 \%$ of all bacterial phyla. The phyla Cyanobacteria and Actinobacteria were the second and third largest members of the bacterial communities, accounting for an average of $25.8 \%$ and $22.4 \%$ of the biofilm communities, respectively. Deinococcus-Thermus represented $10.9 \%$ of the bacterial microflora of the untreated stone.

Within Proteobacteria, $8.7 \%$ of the sequences were members of the genus Acidiphilium, while $8 \%$ of the sequences belonged to the genus Sphingomonas. A major part of the ASVs belonged to uncultured bacteria, which made up $44.5 \%$ of the community. Then followed the genera Quadrisphaera (Actinobacteria; Actinobacteria; Kineosporiales; Kineosporiaceae), and Truepera (Deinococcus-Thermus; Deinococci; Deinococcales; Trueperaceae), which accounted for $11.1 \%$, and $8.3 \%$ of the biofilm community, respectively (Figure 7b, Table S1).

Amplicon sequences of the treated samples were classified into 3 different phyla, the majority of which belonged to the Actinobacteria and Cyanobacteria (uncultured taxa) phyla, accounting for $88.1 \%$ and $9.6 \%$ of the bacterial community, respectively (Figure 7a, Table S1). The most abundant ASV was Quadrisphaera (Actinobacteria; Actinobacteria; Kineosporiales; Kineosporiaceae, 43.0\%). Other abundant ASVs were Microbacterium (Actinobacteria; Actinobacteria; Micrococcales; Microbacteriaceae, 19.9\%) Pseudarthrobacter (Actinobacteria; Actinobacteria; Micrococcales; Micrococcaceae, 13.8\%) and 
Agrococcus (Actinobacteria; Actinobacteria; Micrococcales; Microbacteriaceae, 7.5\%) (Figure 7b, Table S1). The unique ASVs in the treated samples belonged to the genera Agrococcus, Blastococcus, Kocuria and Pseudarthrobacter.

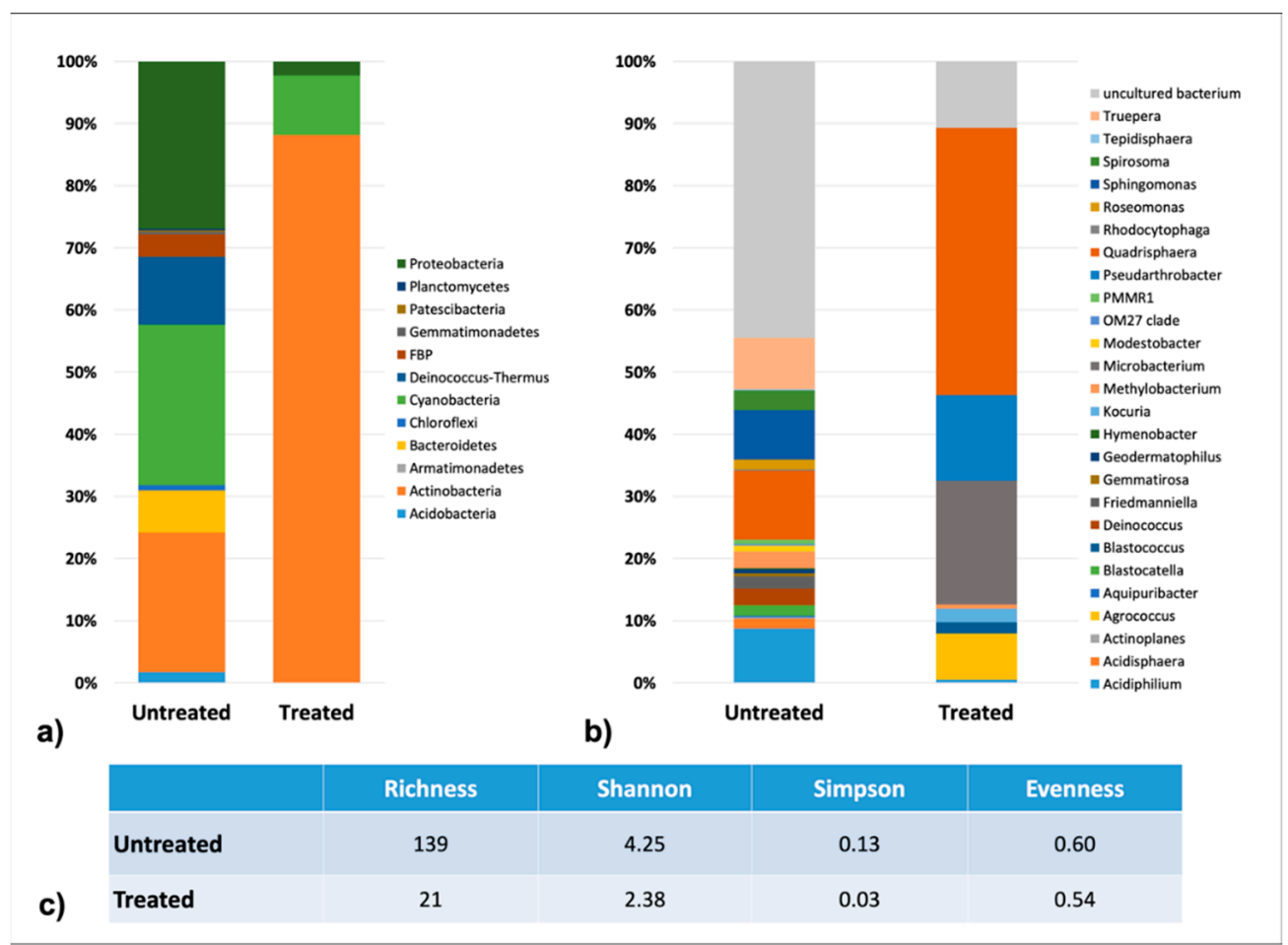

Figure 7. Bacterial community composition on untreated and treated surfaces at phylum (panel a) and genus (panel b) levels. Alpha-diversity indexes of the taxonomic profiles at the $97 \%$-similarity threshold (panel c).

The microorganisms shared between the untreated and treated samples belonged to 11 ASVs, representing 5 Nostocales, 4 Quadrisphaera, 1 Acidiphilium and 1 Beijerinckiaceae.

The Alpha diversity of the bacterial communities was calculated using R. The microbial diversity parameters including Shannon and Simpson indexes were higher in the untreated samples than in the treated samples. These indicated that the richness and diversity of bacterial communities for the untreated surface was higher than for the treated area (Figure 7c). The evenness of the bacterial community exhibited similar trends to the richness: it decreased after the cleaning treatment.

\subsection{Effects of the Cleaning Treatment on Biofilm Functional Profiles}

The molecular investigations indicated that the cleaning treatment affected the overall compositions of the core biofilm community. Furthermore, functional differences might occur, reflecting dramatically altered performances of the biofilm ecosystem. To gain insight into the metabolic contribution of the microflora across untreated and treated surfaces, the predictive tool PICRUSt was used to unravel the functional traits of the bacterial communities observed (Figure 8).

The present study identified 26 gene families in both the untreated and treated samples. Of the 26 gene families, the majority of the genes belonged to carbohydrate metabolism $(10.90 \% \pm 0.72 \%)$, translation $(9.35 \% \pm 0.55 \%)$, amino acid metabolism $(7.96 \% \pm 0.07 \%)$, replication and repair $(5.69 \% \pm$ $0.07 \%)$ and cellular processes and signaling $(5.67 \% \pm 0.30 \%)$.

The ratio of gene families between treated and untreated samples was used to identify changes in the main predicted metabolic pathways of the biofilm which survived after the cleaning procedure. The metabolic pathways that increased and decreased at least two-fold in the treated biofilm are 
represented in Figure 8a,b, respectively. The complete list of the predicted functional diversity of both untreated and treated samples is available in Table S2.

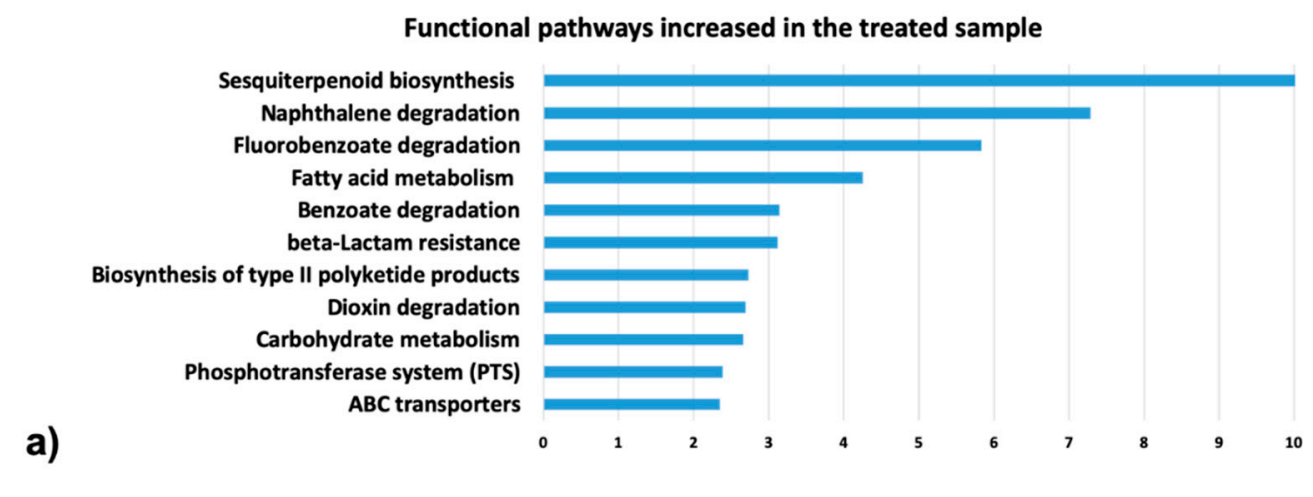

Functional pathways decreased in the treated sample

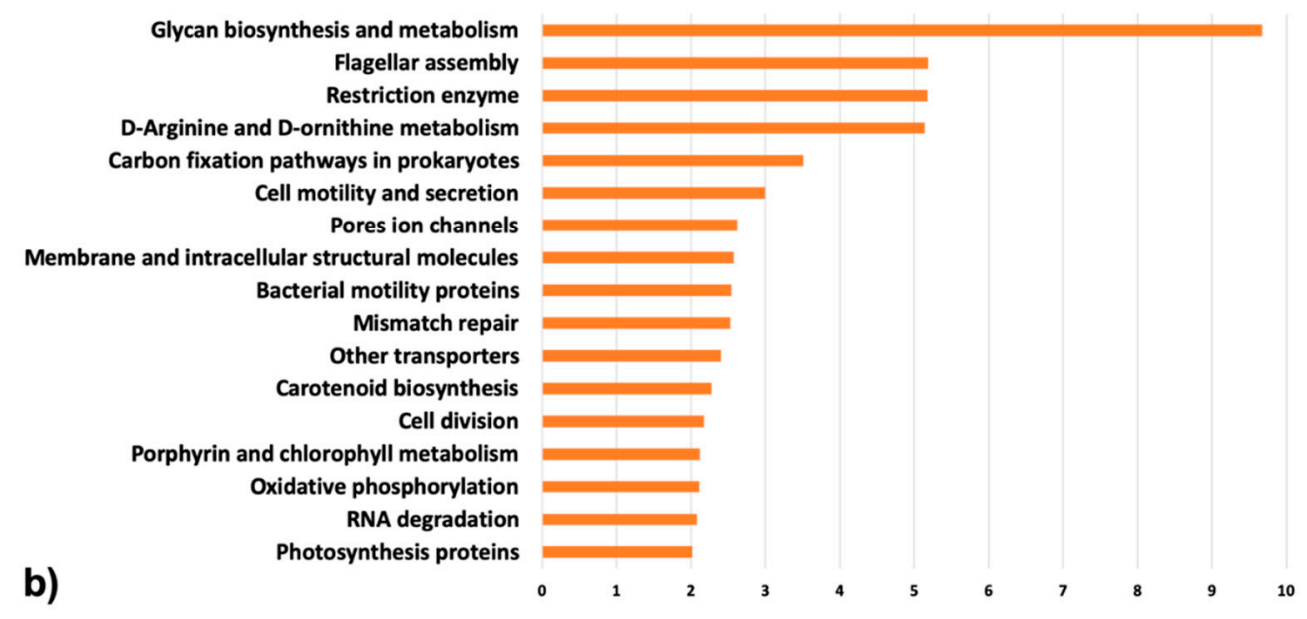

Figure 8. Functional pathways differentially enriched in the treated sample. The metabolic pathways that increased and decreased at least two-fold in the treated biofilm are represented in panels (a) and (b), respectively. Ratios higher than 2 were reported in the graphs.

The results show that metabolic pathways involved in terpenoids and polyketides biosynthesis (e.g. sesquiterpenoid biosynthesis and biosynthesis of type II polyketide products), xenobiotic degradation (benzoate degradation, naphthalene degradation, fluorobenzoate degradation, dioxin degradation), fatty acid metabolism, ATP-binding cassette (ABC) transporters, beta-lactam resistance and carbohydrate metabolism were significantly increased in the treated biofilms in comparison to the untreated ones. By contrast, metabolic pathways related to motility (e.g. bacterial motility proteins, cell motility and secretion, flagellar assembly), photosynthesis (e.g. photosynthesis proteins, porphyrin and chlorophyll metabolism, carotenoid biosynthesis, carbon fixation pathways in prokaryotes) and cell growth and activity (e.g. cell division, membrane and intracellular structural molecules, oxidative phosphorylation, ion channel pores, glycan biosynthesis and metabolism) decreased in the treated samples.

\section{Discussion}

After treatment, the amount of viable cells drastically decreased as seen by microscope observations, but complete biofilm removal was not achieved even after repeated surface brushing and washing in agreement with what has been shown in other works [34], leading to changes to the ecological balance of the microbial community [8]. Rosado et al. [35] demonstrated that different bacterial and fungal taxa display distinctive sensitivity to different biocides. The different solvents and biocidal products 
affected in a specific manner the growth and/or the pigmentation of the four fungal taxa isolated from the sacristy vault of a religious building [18]. Evaluating the effects of the biocide Rohm and Haas Rocima $^{\mathrm{TM}} 103$, Urzì et al. [22] showed that the biocidal treatment had a limited effect on cyanobacteria and strongly decreased community biodiversity.

Even if in the relevant literature a combination of biocides is suggested [22,23], in this research we proved that this strategy did not lead to eradication of the entire microbial community. Incomplete biofilm removal was particularly evident where micro-cracks and discontinuities were present. The residual amount of biofilm was due to cells surviving the treatment, EPS and cellular content leakage, the latter shown by the fluorescence signal. Incomplete removal was a partially expected but, definitely, an undesired finding, as it is known that released cellular constituents and cyanobacterial EPS form a nutrient source for heterotrophic microorganisms [36].

Microscope observations and molecular analysis showed that Cyanobacteria, Proteobacteria and Actinobacteria were the main bacteria present on the untreated Candoglia marble. The microscopic investigations did not show the presence of hyphae and spores that might be correlated to the presence of fungi as also reported in our previous investigation [1]. Alphaproteobacteria are often the predominant taxa on stone buildings [37], and in the Altamira cave they have been found to be the most metabolically active class of the Proteobacteria [38]. Acidiphilium species are obligately acidophilic $(\mathrm{pH}$ range 2.5-5.9) chemoorganotrophic bacteria with high resistance to heavy metals, such as copper, nickel and zinc [39]. Interestingly, metal clamps are present to anchor the marble leaves in place and the stone showed pyrite impurities. Extensively bordered by mountains, the Lombardy region ranks among the most air polluted European areas [40]. Thus acidophilic taxa may be linked to acid rain resulting from gaseous pollutants and particularly $\mathrm{CO}_{2}$ and $\mathrm{NOx}$, emitted into the atmosphere. A striking feature of Acidiphilium is the production of $\mathrm{Zn}-\mathrm{BChl}$ a as the major photopigment only under aerobic conditions. Hiraishi and Shimada [39] proposed that these bacteria are capable of photosynthetic light utilization for their survival in oligotrophic environments. Li et al. [41] considered Sphingomonas a major player in the deterioration of monuments because of its high relative abundance and frequency on heritage stone [42]. However, this genus has been also retrieved in dust samples which may explain its global presence on stone substrata $[43,44]$. Indeed, Sphingomonas and Quadrisphaera, a recently identified actinobacterium [45], were isolated from Antarctic samples [46]. According to Ivanova et al. [47], Truepera radiovictrix, which is the sole and type species of the genus Truepera, grows under multiple extreme conditions in alkaline, moderately saline, high-temperature habitats and ionizing radiation. Among the most representative phyla before treatment were cyanobacteria. They could not be identified, as the majority of cyanobacteria in DNA databanks are not terrestrial but aquatic species [48]. However, consistent with other studies on cyanobacteria dwelling on stone heritage sites, these microorganisms were principally found as coccoid morphotypes $[48,49]$.

As evidenced by sequencing, bacterial diversity greatly decreased after exposure to biocides, with Actinobacteria being the most represented phylum. Actinobacteria produce a wide variety of secondary metabolites, including most of the known antibiotics. By necessity, they often possess resistance mechanisms for self-defense against a variety of biocides [50]. In a paper by Diaz-Herraiz et al. [51], it is reported that only one very major phylogenetic group belonging to Actinobacteria was retrieved on an Etruscan tomb due to the availability of organic matter. Interestingly, the walls had been treated with benzalkonium chloride in 1993 and with dodecyl dimethyl dichlorobenzyl ammonium chloride in 2000 [51].

Q. granulorum is a bacterium first isolated in aerobic granules, a recent innovation in biological wastewater treatment, with the ability to be exposed to high organic loading rates [45]. The analysis of the bacterial community in the production line of a calcium carbonate filler company showed that Pseudomonas and Microbacterium were the most frequent contaminants in the slurry [52]. After biocidal treatment, resistance development was highlighted [52]. Studying the interactions among four bacterial species, including M. saperdae, capable of degrading an industrial coolant and lubricant also containing biocides, Piccardi et al. [53] found only positive or neutral interactions among the taxa. Pseudarthrobacter, 
a taxon retrieved only in the treated samples, has been associated with pollutants including heavy metals. Pseudarthrobacter was among the main genera with a strong ability to immobilize heavy metal and to remove $\mathrm{Cd}$ and $\mathrm{Pb}$ from soil [54]. Opencast coal mining and burning of coal for electricity is an environmental concern in the Xilingol grassland ecosystem [55]. In the coal environment, the most abundant genus was Pseudarthrobacter. During a survey by genome mining, P. phenanthrenivorans J015 was found to be able to degrade phenanthrene and tolerant to Cr VI [56]. In a study of the family Microbacteriaceae using gene-sequence phylogenies, Agrococcus jenensis showed identity with M. saperdae in three gene trees [57]. The species A. carbonis and A. citreus were isolated for the first time from soil of a coal mine [58] and from a medieval wall painting of the chapel of Castle Herberstein, Austria, [59] respectively. In a survey carried out in 2006, a Kocuria species has been reported in US Air Force aviation fuel not previously retrieved [60]. This change in the microbial community was also putatively related to changes in biocide use in aviation fuel. Blastococcus has shown very high resistance to metals [61].

The predicted functional profiling of the bacterial communities using 16S rRNA marker gene sequences was also obtained. PICRUSt has been applied in many authoritative works to estimate the metabolic pathways of bacterial communities retrieved in different ecosystems, including mineral-based substrates [62-68]. By predicting metabolic pathways, a consensus of the microbial metabolic characteristics present in an environment and the possible interactions of the microbial communities with the abiotic environment can be obtained. The treated samples featured putative functional genes related to sesquiterpenoid biosynthesis, xenobiotic degradation, fatty acid metabolism, ABC transporters, beta-lactam resistance and carbohydrate metabolism.

Actinobacteria are well known to produce terpenoids and polyketides as antibiosis molecules to protect their resources from being used by other microorganisms and to establish a secure ecological niche [69-71]. The shift in a new bacterial community emerged also from the observation that the treated samples displayed genes mainly associated with a heterotrophic lifestyle (including genes for central carbohydrate metabolism, the phosphotransferase system and tricarboxylic acid cycle cycle), while $\mathrm{CO}_{2}$-fixation pathways were dramatically reduced. This finding was also supported by the microscopic investigations that showed non-viable cyanobacteria and the presence of intracellular material spread across the mineral surface, which may encourage the prevalence of a heterotrophic lifestyle.

PICRUSt predicted an increased capacity of the treated biofilm community to degrade xenobiotics and to resist beta-lactams. In the Lascaux cave, Bastian et al. [72] showed that years of treatments with benzalkonium chloride have selected a bacterial community highly resistant to the molecule and capable of degrading it. Additionally, the fungal species Exophiala has been found in the Lascaux Cave after benzalkonium chloride treatment [23]. Exophiala is present in environments rich in aromatic compounds, in which they also metabolize alkylbenzenes as the sole source of carbon [23]. Quaternary ammonium compounds, such as benzalkonium chloride, were proved to select bacteria exhibiting reduced susceptibility to the primary antimicrobial compound and potentially to unrelated biocides and antibiotics [73-75]. Kim et al. [76] revealed that benzalkonium chloride exposure can induce antibiotic resistance via multiple genetic mechanisms, including the co-occurrence of benzalkonium chlorides tolerance and antibiotic resistance genes on the same mobile DNA molecule, mutations in the $p m r B$ gene, and the induction of efflux pump expression.

Ceragioli et al. [77] demonstrated that exposure of Bacillus cereus ATCC 14,579 to benzalkonium chloride specifically induced genes involved in fatty acid metabolism. The researchers proposed that this finding correlates with the benzalkonium chloride mode of action that is the ability to cause membrane damage.

Interestingly, ATP-binding cassette $(\mathrm{ABC})$ transporters increased in the treated samples. ABC transporters are an important class of related proteins performing transportation of different substrates, ranging from sugars to antibiotics [78]. Ample evidence suggests that ABC transporters can confer resistance to antimicrobials and can be responsible for a low bioavailability of these compounds by pumping the molecules out of cells at the expense of ATP hydrolysis [79]. Li et al. [64] used PICRUSt 
to predict the functional performance of a microbiota associated with stone deterioration. The authors observed an increase in the $\mathrm{ABC}$ transporter system in the deterioration-associated microbiome, which may affect the complex exchange of molecules and metal complexes in densely packed biofilm communities. Recently, Jiang et al. [80] reported that two ABC transporters, VirAB and AnrAB, were involved in nisin and bacitracin resistance, as well as resistance to cephalosporins, ethidium bromide, and benzalkonium chloride in Listeria monocytogenes.

The functional profiles predicted by PICRUSt also indicated loss of motility and bacterial fitness, which is in line with the results of a previous study showing that exposure to environmentally relevant concentrations of benzalkonium chloride reduced the growth rate and biofilm formation in Escherichia coli, increased the expression of genes associated with efflux and reduced the expression of genes associated with outer-membrane porins, motility, and chemotaxis [81].

Collectively, these findings indicate that despite the acceptable aesthetic results obtained, the overall cleaning treatment is only partially effective in removing the biofilm from the colonized surfaces and, therefore, is not adequately suitable for the specific substrate. This can be ascribed both to the selection of the type of biocides and to the following mechanical cleaning procedures. In presence of severely deteriorated surfaces, such as the eroded and highly micro-cracked crystalline microstructure of Candoglia marble, simple mechanical brushing is clearly not able to completely remove the biofilm matrix and dead cells from the stone substrate. Furthermore, despite the use of three biocides, the cleaning selected left behind microorganisms potentially more resistant to them so that a future use of antimicrobial agents could imply a less efficient result. Conservators are rarely aware of the intrinsic limit of their treatments and conservation plans are made on the basis of short-term aesthetic results rather than on assessed efficacy tests.

Supplementary Materials: The following are available online at http://www.mdpi.com/2079-6412/10/2/122/s1: Table S1: complete list of the predicted functional diversity of both untreated and treated samples.

Author Contributions: Conceptualization, F.V. and F.C.; Methodology, D.G., L.B. and C.C.; Data Curation, L.T.; Writing-Original Draft Preparation, F.V. and F.C.; Writing—Review and Editing, D.G., L.B., C.C. and L.T.; All authors have read and agreed to the published version of the manuscript.

Funding: This research received no external funding.

Conflicts of Interest: The authors declare no conflict of interest.

\section{References}

1. Gulotta, D.; Villa, F.; Cappitelli, F.; Toniolo, L. Biofilm colonization of metamorphic lithotypes of a renaissance cathedral exposed to urban atmosphere. Sci. Total Environ. 2018, 639, 1480-1490. [CrossRef] [PubMed]

2. Rodrigues, J.D.; Anjos, M.V.; Charola, A.E. Recolonization of marble sculptures in a garden environment. In Biocolonization of Stone: Control and Preventative Methods; Charola, A.E., McNamara, C., Koestler, R.J., Eds.; Smithsonian Institution Scholarly Press: Washington, WA, USA, 2011; pp. 71-84.

3. Matteucci, E.; Scarcella, A.V.; Croveri, P.; Marengo, A.; Borghi, A.; Benelli, C.; Hamdan, O.; Favero-Longo, S.E. Lichens and other lithobionts on the carbonate rock surfaces of the heritage site of the tomb of Lazarus (Palestinian territories): Diversity, biodeterioration, and control issues in a semi-arid environment. Ann. Microbiol. 2019, 69, 1033-1046. [CrossRef]

4. Nowicka-Krawczyk, P.; Żelazna-Wieczorek, J.; Koźlecki, T. Silver nanoparticles as a control agent against facades coated by aerial algae-A model study of Apatococcus lobatus (green algae). PLoS ONE 2017, 12, e0183276. [CrossRef] [PubMed]

5. Sanmartín, P.; Villa, F.; Polo, A.; Silva, B.; Prieto, B.; Cappitelli, F. Rapid evaluation of three biocide treatments against the cyanobacterium Nostoc sp. PCC 9104 by color changes. Ann. Microbiol. 2015, 65, 1153-1158.

6. Savvides, A.L.; Nikolakopoulou, T.L.; Kyratsous, N.; Katsifas, E.A.; Kanini, G.; Karagouni, A.D. Bacterial deterioration of marble monuments: A case study of the Conservation Project of Acropolis Monuments. Geomicrobiol. J. 2014, 31, 726-736. [CrossRef]

7. Shirakawa, M.A.; Gaylarde, C.C.; Gaylarde, P.M.; John, V.; Gambale, W. Fungal colonization and succession on newly painted buildings and the effect of biocide. FEMS Microbiol. Ecol. 2002, 39, 165-173. [CrossRef] 
8. Sterflinger, K.; Piñar, G. Microbial deterioration of cultural heritage and works of art — tilting at windmills? Appl. Microbiol. Biotechnol. 2013, 97, 9637-9646. [CrossRef]

9. Mulder, I.; Siemens, J.; Sentek, V.; Amelung, W.; Smalla, K.; Jechalke, S. Quaternary ammonium compounds in soil: Implications for antibiotic resistance development. Rev. Environ. Sci. Biotechnol. 2018, 17, 159-185. [CrossRef]

10. Faimon, J.; Štelcl, J.; Kubešová, S.; Zimák, J. Environmentally acceptable effect of hydrogen peroxide on cave "lamp-flora", calcite speleothems and limestones. Environ. Pollut. 2003, 122, 417-422. [CrossRef]

11. Mulec, J.; Kosi, G. Lampenflora algae and methods of growth control. J. Cave Karst Stud. 2009, 71, $109-115$.

12. Jurado, V.; Porca, E.; Cuezva, S.; Fernandez-Cortes, A.; Sanchez-Moral, S.; Saiz-Jimenez, C. Fungal outbreak in a show cave. Sci. Total Environ. 2010, 408, 3632-3638. [CrossRef] [PubMed]

13. Hernandez-Marine, M.; Gonzalez-del Valle, M.A.; Ortiz-Martinez, A.; Laiz, L.; Saiz-Jimenez, C. Effect of Algophase on the cyanobacterium Gloeothece membranacea CCAP 1430/3. In Molecular Biology and Cultural Heritage; Saiz-Jimenez, C., Ed.; Swets \& Zeitlinger: Lisse, The Netherlands, 2003; pp. 195-200.

14. Tretiach, M.; Crisafulli, P.; Imai, N.; Kashiwadani, H.; Moon, K.H.; Wada, H.; Salvadori, O. Efficacy of a biocide tested on selected lichens and its effects on their substrata. Int. Biodeter. Biodegr. 2007, 59, 44-54. [CrossRef]

15. Maxwell, I. Cleaning Sandstone: Risks and Consequences. Inform: Information for Historic Building Owners. Historic Scotland, Technical Conservation, Research and Education Group: Edinburgh, UK. Available online: https://www.historicenvironment.scot/archives-and-research/publications/publication/ ?publicationid=cfcd9855-eff4-40d7-9ccf-a59500b10077 (accessed on 16 December 2019).

16. Leplat, J.; Francois, A.; Bousta, F. White fungal covering on the wall paintings of the Saint-Savin-sur-Gartempe Abbey church crypt: A case study. Int. Biodeter. Biodegr. 2017, 122, 29-37. [CrossRef]

17. Mitova, M.M.; Iliev, M.; Nováková, A.; Gorbushina, A.A.; Groudeva, V.I.; Martin-Sanchez, P.M. Diversity and biocide susceptibility of fungal assemblages dwelling in the Art Gallery of Magura Cave, Bulgaria. Int. J. Speleol. 2017, 46, 67-80. [CrossRef]

18. Favero-Longo, S.E.; Brigadeci, F.; Segimiro, A.; Voyrona, S.; Cardinali, M.; Girlanda, M.; Piervittori, R. Biocide efficacy and consolidant effect on the mycoflora of historical stuccos in indoor environment. J. Cult. Herit. 2018, 34, 33-42. [CrossRef]

19. Warscheid, T.; Leisen, H. Microbiological studies on stone deterioration and development of conservation measures at Angkor Wat. In Biocolonization of Stone: Control and Preventative Methods; Charola, A.E., McNamara, C., Koestler, R.J., Eds.; Smithsonian Institution Scholarly Press: Washington, WA, USA, 2011; pp. 1-18.

20. Barresi, G.; Cammarata, M.; Palla, F. Biocide. In Biotechnology and Conservation of Cultural Heritage; Palla, F., Barresi, G., Eds.; Springer: Cham, Switzerland, 2017; pp. 49-65.

21. Ascaso, C.; Wierzchos, J.; Souza-Egipsy, V.; de los Rios, A.; Delgado Rodrigues, J. In situ evaluation of the biodeteriorating action of microorganisms and the effects of biocides on carbonate rock of the Jeronimos Monastery (Lisbon). Int. Biodeter. Biodegr. 2002, 49, 1-12. [CrossRef]

22. Urzì, C.; De Leo, F.; Krakova, L.; Pangallo, D.; Bruno, L. Effects of biocide treatments on the biofilm community in Domitilla's catacombs in Rome. Sci. Total Environ. 2016, 572, 252-262. [CrossRef]

23. Martin-Sanchez, P.M.; Nováková, A.; Bastian, F.; Alabouvette, C.; Saiz-Jimenez, C. Use of biocides for the control of fungal outbreaks in subterranean environments: The case of the Lascaux cave in France. Environ. Sci. Technol. 2012, 46, 3762-3770. [CrossRef]

24. Gulotta, D.; Toniolo, L. Conservation of the built heritage: Pilot site approach to design a sustainable process. Heritage 2019, 2, 797-812. [CrossRef]

25. Villa, F.; Pitts, B.; Lauchnor, E.; Cappitelli, F.; Stewart, P. Development of a laboratory model of a phototroph-heterotroph mixed-species biofilm at the stone/air interface. Front. Microbiol. 2015, 6, 1251. [CrossRef]

26. Roldán, M.; Ascaso, C.; Wierzchos, J. Fluorescent fingerprints of endolithic phototrophic cyanobacteria living within halite rocks in the Atacama Desert. Appl. Environ. Microbiol. 2014, 80, 2998-3006. [CrossRef] [PubMed]

27. Polo, A.; Gulotta, D.; Santo, N.; Di Benedetto, C.; Fascio, U.; Toniolo, L.; Villa, F.; Cappitelli, F. Importance of subaerial biofilms and airborne microflora in the deterioration of stonework: A molecular study. Biofouling 2012, 28, 1093-1106. [CrossRef] [PubMed] 
28. Rapin, A.; Pattaroni, C.; Marsland, B.J.; Harris, N.L. Microbiota analysis using an illumina MiSeq platform to sequence 16S rRNA genes. Curr. Protoc. Mouse Biol. 2017, 7, 100-129. [CrossRef] [PubMed]

29. Bolyen, E.; Rideout, J.R.; Dillon, M.R.; Bokulich, N.A.; Abnet, C.C.; Al-Ghalith, G.A.; Alexander, H.; Alm, E.J.; Arumugam, M.; Asnicar, F.; et al. Reproducible, interactive, scalable and extensible microbiome data science using QIIME 2. Nat. Biotechnol. 2019, 37, 852-857. [CrossRef]

30. Callahan, B.J.; McMurdie, P.J.; Rosen, M.J.; Han, A.W.; Johnson, A.J.A.; Holmes, S.P. DADA2: High resolution sample inference from Illumina amplicon data. Nat. Methods 2016, 13, 581-583. [CrossRef]

31. Quast, C.; Pruesse, E.; Yilmaz, P.; Gerken, J.; Schweer, T.; Yarza, P.; Peplies, J.; Glöckner, F.O. The SILVA ribosomal RNA gene database project: Improved data processing and web-based tools. Nucleic Acids Res. 2013, 41, D590-D596. [CrossRef]

32. Douglas, G.M.; Maffei, V.J.; Zaneveld, J.; Yurgel, S.N.; Brown, J.R.; Taylor, C.M.; Huttenhower, C.; Langille, M.G.I. PICRUSt2: An improved and extensible approach for metagenome inference. BioRxiv 2019, 672295.

33. R Core Team. R: A Language and Environment for Statistical Computing. R Foundation for Statistical Computing: Vienna, Austria. Available online: http://www.r-project.org/ (accessed on 16 December 2019).

34. De Leo, F.; Iero, A.; Zammit, G.; Urzì, C. Chemoorganotrophic bacteria isolated from biodeteriorated surfaces in cave and catacombs. Int. J. Speleol. 2012, 41, 125-136. [CrossRef]

35. Rosado, T.; Gil, M.; Caldeira, A.T.; Martins, M.D.R.; Dias, C.B.; Carvalho, L.; Candeias, A.E. Material characterization and biodegradation assessment of mural paintings: Renaissance frescoes from Santo Aleixo Church, Southern Portugal. Int. J. Archit. Herit. 2014, 8, 835-852. [CrossRef]

36. Di Martino, P. What about biofilms on the surface of stone monuments? Open Conf. Proc. J. 2016, 7, 14-28. [CrossRef]

37. Berdoulay, M.; Salvado, J.C. Genetic characterization of microbial communities living at the surface of building stones. Lett. Appl. Microbiol. 2009, 49, 311-316. [CrossRef] [PubMed]

38. Portillo, M.C.; Saiz-Jimenez, C.; Gonzalez, J.M. Molecular characterization of total and metabolically active bacterial communities of "white colonizations" in the Altamira cave, Spain. Res. Microbiol. 2009, 160, 41-47. [CrossRef] [PubMed]

39. Hiraishi, A.; Shimada, K. Aerobic anoxygenic photosynthetic bacteria with zinc-bacteriochlorophyll. J. Gen. Appl. Microbiol. 2001, 47, 161-180. [CrossRef] [PubMed]

40. Carugno, M.; Consonni, D.; Randia, G.; Catelan, D.; Grisotto, L.; Bertazzi, P.A.; Biggeri, A.; Baccini, M. Air pollution exposure, cause-specific deaths and hospitalizations in a highly polluted Italian region. Environ. Res. 2016, 147, 415-424. [CrossRef]

41. Li, Q.; Zhang, B.; He, Z.; Yang, X. Distribution and diversity of bacteria and fungi colonization in stone monuments analyzed by high-throughput sequencing. PLoS ONE 2016, 11, e0163287. [CrossRef]

42. Miller, A.Z.; Laiz, L.; Dionísio, A.; Macedo, M.F.; Saiz-Jimenez, C. Growth of phototrophic biofilms from limestone monuments under laboratory conditions. Int. Biodeter. Biodegr. 2009, 63, 860-867. [CrossRef]

43. Favet, J.; Lapanje, A.; Giongo, A.; Kennedy, S.; Aung, Y.-Y.; Cattaneo, A.; Davis-Richardson, A.G.; Brown, C.T.; Kort, R.; Brumsack, H.-J.; et al. Microbial hitchhikers on intercontinental dust: Catching a lift in Chad. ISME J. 2013, 7, 850-867. [CrossRef]

44. Brewer, T.E.; Fierer, N. Tales from the tomb: The microbial ecology of exposed rock surfaces. Environ. Microbiol. 2018, 20, 958-970. [CrossRef]

45. Maszenan, A.M.; Tay, J.-H.; Schumann, P.; Jiang, H.-L.; Tay, S.T.-L. Quadrisphaera granulorum gen. nov.; sp. nov.; a Gram-positive polyphosphate-accumulating coccus in tetrads or aggregates isolated from aerobic granules. Int. J. Syst. Evol. Microbiol. 2005, 55, 1771-1777. [CrossRef]

46. Pulschen, A.A.; Bendia, A.G.; Fricker, A.D.; Pellizari, V.H.; Galante, D.; Rodrigues, F. Isolation of uncultured bacteria from Antarctica using long incubation periods and low nutritional media. Front. Microbiol. 2017, 8 , 1346. [CrossRef]

47. Ivanova, N.; Rohde, C.; Munk, C.; Nolan, M.; Lucas, S.; Glavina Del Rio, T.; Tice, H.; Deshpande, S.; Cheng, J.; Tapia, R. Complete genome sequence of Truepera radiovictrix type strain (RQ-24T). Stand. Genomic Sci. 2011, 4, 91-99. [CrossRef] [PubMed]

48. Gaylarde, C.C.; Gaylarde, P.M.; Copp, J.; Neilan, B. Polyphasic detection of cyanobacteria in terrestrial biofilms. Biofouling 2004, 20, 71-79. [CrossRef] [PubMed] 
49. Hauer, T.; Mühlsteinová, R.; Bohunická, M.; Kaštovský, J.; Mareš, J. Diversity of cyanobacteria on rock surfaces. Biodivers. Conserv. 2015, 24, 759-779. [CrossRef]

50. Lee, L.-F.; Huang, Y.-J.; Chen, C.W. Repressed multidrug resistance genes in Streptomyces lividans. Arch. Microbiol. 2003, 180, 176-184. [CrossRef] [PubMed]

51. Diaz-Herraiz, M.; Jurado, V.; Cuezva, S.; Laiz, L.; Pallecchi, P.; Tiano, P.; Sanchez-Moral, S.; Saiz-Jimenez, C. The actinobacterial colonization of Etruscan paintings. Sci. Rep. 2013, 3, 1440. [CrossRef] [PubMed]

52. Odić, D.; Prah, J.; Avguštin, G. Identification of bacterial contaminants from calcium carbonate filler production lines and an evaluation of biocide based decontamination procedures. Biofouling 2017, 33, 327-335. [CrossRef]

53. Piccardi, P.; Vessman, B.; Mitri, S. Toxicity drives facilitation between 4 bacterial species. PNAS 2019, 116, 15979-15984. [CrossRef]

54. Wang, T.-J.; Su, N.-N.; Lei, P.; Qiu, M.-Y.; Chen, Z.-J.; Yao, L.-G.; Han, H.E. Community structure of heavy metal immobilized bacteria in the lettuce (Lactuca sativa L.) rhizosphere in soil polluted by heavy metals and its effects on reducing heavy metal accumulation in lettuce. Huanjing Kexue/Environ. Sci. 2019, 40, 5133-5141.

55. Wang, B.; Wang, Y.; Cui, X.; Zhang, Y.; Yu, Z. Bioconversion of coal to methane by microbial communities from soil and from an opencast mine in the Xilingol grassland of northeast China. Biotechnol. Biofuels 2019, 12, 236. [CrossRef]

56. Huang, Y.; Wang, Y.; Feng, H.; Wang, Y.; Yang, X.; Wang, Z. Genome-guided identification and characterization of bacteria for simultaneous degradation of polycyclic aromatic hydrocarbons and resistance to hexavalent chromium. Int. Biodeter. Biodegr. 2019, 138, 78-86. [CrossRef]

57. Stackebrandt, E.; Brambilla, E.; Richert, K. Gene sequence phylogenies of the family Microbacteriaceae. Curr. Microbiol. 2007, 55, 42-46. [CrossRef] [PubMed]

58. Dhanjal, S.; Kaur, I.; Korpole, S.; Schumann, P.; Singh Cameotra, S.; Pukall, R.; Klenk, H.-P.; Mayilraj, S. Agrococcus carbonis sp. nov., isolated from soil of a coal mine. Int. J. Syst. Evol. Microbiol. 2011, 61, 1253-1258. [CrossRef] [PubMed]

59. Wieser, M. Agrococcus citreus sp. nov.; isolated from a medieval wall painting of the chapel of Castle Herberstein (Austria). Int. J. Syst. Bacteriol. 1999, 49, 1165-1170. [CrossRef] [PubMed]

60. Rauch, M.E.; Graef, H.W.; Rozenzhak, S.M.; Jones, S.E.; Bleckmann, C.A.; Kruger, R.L.; Naik, R.R.; Stone, M.O. Characterization of microbial contamination in United States Air Force aviation fuel tanks. J. Ind. Microbiol. Biotechnol. 2006, 33, 29-36. [CrossRef] [PubMed]

61. Tekaya, S.B.; Tipayno, S.; Kim, K.; Subramanian, P.; Sa, T. Rhizobacteria: Restoration of Heavy Metal-Contaminated Soils. In Physiological Mechanisms and Adaptation Strategies in Plants Under Changing Environment; Ahmad, P., Wani, M., Eds.; Springer: New York, NY, USA, 2014; pp. 297-323.

62. Li, H.; Chi, Z.; Li, J.; Wu, H.; Yan, B. Bacterial community structure and function in soils from tidal freshwater wetlands in a Chinese delta: Potential impacts of salinity and nutrient. Sci Total Environ. 2019, 696, 134029. [CrossRef]

63. Li, J.; Cai, M.H.; Miao, Y.; Luo, G.; Li, W.T.; Li, Y.; Li, A.M. Bacterial community structure and predicted function in an acidogenic sulfate-reducing reactor: Effect of organic carbon to sulfate ratios. Bioresour. Technol. 2019, 293, 122020. [CrossRef]

64. Li, Q.; Zhang, B.; Yang, X.; Ge, Q. Deterioration-associated microbiome of stone monuments: Structure, variation, and assembly. Appl. Environ. Microbiol. 2018, 84, e02680-17. [CrossRef]

65. De Mandal, S.; Chatterjee, R.; Kumar, N.S. Dominant bacterial phyla in caves and their predicted functional roles in C and N cycle. BMC Microbiol. 2017, 17, 90. [CrossRef]

66. Ren, Z.; Gao, H.; Elser, J.J.; Zhao, Q. Microbial functional genes elucidate environmental drivers of biofilm metabolism in glacier-fed streams. Sci Rep. 2017, 7, 12668. [CrossRef]

67. Bomberg, M.; Lamminmäki, T.; Itävaara, M. Microbial communities and their predicted metabolic characteristics in deep fracture groundwaters of the crystalline bedrock at Olkiluoto, Finland. Biogeosciences 2016, 13, 6031-6047. [CrossRef]

68. Vikram, S.; Guerrero, L.D.; Makhalanyane, T.P.; Le, P.T.; Seely, M.; Cowan, D.A. Metagenomic analysis provides insights into functional capacity in a hyperarid desert soil niche community. Environ. Microbiol. 2016, 18, 1875-1888. [CrossRef] [PubMed] 
69. Shirai, M.; Okuda, M.; Motohashi, K.; Imoto, M.; Furihata, K.; Matsuo, Y.; Katsuta, A.; Shizuri, Y.; Seto, H. Terpenoids produced by actinomycetes: Isolation, structural elucidation and biosynthesis of new diterpenes, gifhornenolones A and B from Verrucosispora gifhornensis YM28-088. J. Antibiot. (Tokyo) 2010, 63, 245-250. [CrossRef] [PubMed]

70. Moody, S.C.; Zhao, B.; Lei, L.; Nelson, D.R.; Mullins, J.G.; Waterman, M.R.; Kelly, S.L.; Lamb, D.C. Investigating conservation of the albaflavenone biosynthetic pathway and CYP170 bifunctionality in streptomycetes. FEBS J. 2012, 279, 1640-1649. [CrossRef] [PubMed]

71. Park, J.S.; Kwon, H.C. New naphthoquinone terpenoids from marine actinobacterium, Streptomyces sp. CNQ-509. Mar. Drugs 2018, 16, 90. [CrossRef] [PubMed]

72. Bastian, F.; Alabouvette, C. Lights and shadows on the conservation of a rock art cave: The case of Lascaux Cave. Int. J. Speleol. 2009, 38, 55-60. [CrossRef]

73. Jones, M.; Herd, T.; Christie, H. Resistance of Pseudomonas aeruginosa to amphoteric and quaternary ammonium biocides. Microbios 1989, 58, 49-61.

74. Levy, S.B. Active efflux, a common mechanism for biocide and antibiotic resistance. J. Appl. Microbiol. 2002, 92, 65S-71S. [CrossRef]

75. Nagai, K.; Murata, T.; Ohta, S.; Zenda, H.; Ohnishi, M.; Hayashi, T. Two different mechanisms are involved in the extremely high-level benzalkonium chloride resistance of a Pseudomonas fluorescens strain. Microbiol. Immunol. 2003, 47, 709-715. [CrossRef]

76. Kim, M.; Weigand, M.R.; Oh, S.; Hatt, J.K.; Krishnan, R.; Tezel, U.; Pavlostathis, S.G.; Konstantinidis, K.T. Widely used benzalkonium chloride disinfectants can promote antibiotic resistance. Appl. Environ. Microbiol. 2018, 84, e01201-18. [CrossRef]

77. Ceragioli, M.; Mols, M.; Moezelaar, R.; Ghelardi, E.; Senesi, S.; Abee, T. Comparative transcriptomic and phenotypic analysis of the responses of Bacillus cereus to various disinfectant treatments. Appl. Environ. Microbiol. 2010, 76, 3352-3360. [CrossRef]

78. Ahmad, A.; Majaz, S.; Nouroz, F. Two-component systems regulate ABC transporters in antimicrobial peptide production, immunity and resistance. Microbiology 2019. [CrossRef] [PubMed]

79. Greene, N.P.; Kaplan, E.; Crow, A.; Koronakis, V. Antibiotic resistance mediated by the macB ABC transporter family: A structural and functional perspective. Front. Microbiol. 2018, 9, 950. [CrossRef] [PubMed]

80. Jiang, X.; Geng, Y.; Ren, S.; Yu, T.; Li, Y.; Liu, G.; Wang, H.; Meng, H.; Shi, L. The VirAB-VirSR-AnrAB multicomponent system is involved in resistance of Listeria monocytogenes EGD-e to cephalosporins, bacitracin, nisin, benzalkonium chloride, and ethidium bromide. Appl. Environ. Microbiol. 2019, 85, e01470-19. [CrossRef] [PubMed]

81. Forbes, S.; Morgan, N.; Humphreys, G.J.; Amézquita, A.; Mistry, H.; McBain, A.J. Loss of function in Escherichia coli exposed to environmentally relevant concentrations of benzalkonium chloride. Appl. Environ. Microbiol. 2019, 85, e02417-18. [CrossRef] [PubMed]

(C) 2020 by the authors. Licensee MDPI, Basel, Switzerland. This article is an open access article distributed under the terms and conditions of the Creative Commons Attribution (CC BY) license (http://creativecommons.org/licenses/by/4.0/). 